\title{
A method for detecting Shiga toxin and Shiga-like toxin-I in pure and mixed culture
}

\author{
S. ASHKENAZI and T. G. CLEARY*
}

\section{Division of Infectious Diseases, Department of Pediatrics, University of Texas Medical School, Houston, USA}

\begin{abstract}
Summary. Shiga toxin and Shiga-like toxins (SLTs, syn. Verotoxins) are currently detected by tissue culture assays that are expensive, time-consuming and require specialised facilities and experienced personnel. We have developed a rapid method to detect Shiga toxin and SLT-I (Verotoxin 1) based on their binding to globotriosyl ceramide $\left(\mathrm{Gb}_{3}\right)$. Bound toxin was then detected by an enzyme-linked immunosorbent assay (ELISA) with monoclonal antibodies. The direct detection of cytotoxins from pure culture plates and from a mixed bacterial culture was studied. Using polymyxin extraction $\left(0 \cdot 1 \mathrm{~g} / \mathrm{L}, 30 \mathrm{~min}, 37^{\circ} \mathrm{C}\right)$ and $\mathrm{Gb}_{3}$-based ELISA we detected toxin from reference strains Shigella dysenteriae 1 strain 60R (Shiga toxin) and Escherichia coli O26:H11 strain H30 (SLT-I), and from clinical isolates of E. coli O157:H7 and O26:H11 (both SLT-I) from 11 patients with diarrhoea, haemorrhagic colitis or haemolytic uraemic syndrome. Toxin production by these strains was confirmed by a radiolabelled HeLa cell assay and the structural genes were detected by DNA hybridisation. The $\mathrm{Gb}_{3}$-based ELISA could detect SLT-I in extracts of a mixed culture even when the toxin-positive strains represented only $1 \%$ of the mixture. No cross-reactivity was found with bacteria that produce other cytotoxins, such as other E. coli and Shigella, Salmonella, Aeromonas and Campylobacter spp.
\end{abstract}

\section{Introduction}

Enteric bacteria that produce cytotoxins have been recognised increasingly as important causes of human disease. ${ }^{1}$ They can cause diarrhoea or haemorrhagic colitis, ${ }^{2,3}$ and are thought to play a major pathogenic role in the haemolytic-uraemic syndrome (HUS) and thrombotic thrombocytopenic purpura ${ }^{4-6}$ The cytotoxins implicated in these diseases include Shiga toxin, and the closely related Shiga-like toxins (SLTs), also known as Verotoxins, produced by Escherichia coli. ${ }^{7-10}$ At least two immunologically distinct toxins, SLT-I and SLT-II (Verotoxins 1 and 2), have been defiped. ${ }^{11,12}$ SLT-I is neutralised by antibodies against Shiga toxin, to which it is virtually identical; there is only a three-nucleotide difference, resulting in a single amino acid difference, between the two toxins. ${ }^{13}$ Although SLT-II is immunologically distinct, this family of toxins is very similar in structure, mechanism of action, binding receptor

Received 22 Nov. 1989; accepted 22 Jan. 1990.

* Correspondence should be sent to: Dr T. G. Cleary, Pediatric Infectious Diseases, University of Texas Medical School, 6431 Fannin Street, Room 1.739, Houston, TX 77030, USA. and biological activities. ${ }^{14-18} \mathrm{~A}$ variant of SLT-II, which is produced by $E$. coli strains associated with oedema disease in pigs ${ }^{19}$ or human $\mathrm{HUS}^{20}{ }^{20}$ has been defined, cloned and sequenced. ${ }^{19}$

Detection of these cytotoxins in the routine clinical laboratory presents considerable difficulty. Toxins are usually detected by their ability to cause cytopathic effects in several cell lines. Radiolabelled DNA probes ${ }^{8,21}$ are still not widely used. Detection of the toxins by enzyme-linked immunosorbent assay (ELISA) has been reported..$^{22-24}$ We have described a rapid and sensitive assay to detect Shiga toxin and SLT-I based on binding to globotriosyl ceramide $\left(\mathrm{Gb}_{3}\right){ }^{25}$ However, preparation of suitable bacterial specimens required growth of cultures for $48 \mathrm{~h}$ and subsequent sonication-a prolonged and cumbersome extraction procedure. Since polymyxin extraction has been shown to be effective in releasing high levels of toxins from the periplasmic space of gram-negative bacteria, ${ }^{26,27}$ it may provide a simpler extraction procedure. Furthermore, the need to examine individual colonies presents problems, because cytotoxinproducing bacteria are typically presented in low numbers in stool samples of patients with diarrhoea and, in particular, HUS. The proportion of cyto- 
toxin-producing colonies is often only $5-20 \%{ }^{4}$ or even lower. ${ }^{28}$

The objectives of the present study were to evaluate the efficacy of a $\mathrm{Gb}_{3}$-based ELISA for detection of Shiga toxin and SLT-I released by polymyxin extraction, both from bacteria grown on various pure culture plates and, most importantly, directly from a mixed bacterial culture. Results of $\mathrm{Gb}_{3}$ ELISA were compared with the quantitative radiolabelled HeLa cell cytotoxicity assay, ${ }^{29,30}$ and with detection of the structural genes for toxin production by DNA hybridisation. ${ }^{8}$

\section{Materials and methods}

\section{Bacteria}

Three reference bacterial strains that produce Shiga toxin and SLT-I were used initially for developing the extraction procedure and the assay: Shigella dysenteriae serotype 1 strain 60R (Shiga toxin); E. coli serotype O26:H11, strain H30 (SLT-I), originally described by J. Konowalchuk; ${ }^{9}$ and E. coli serotype 0157:H7 (SLT-I), provided by J. Mathewson, who originally obtained the strain from R. Wilson, E. coli Reference Center, Pennsylvania State University. For specificity studies, other reference strains were used: $E$. coli $\mathrm{K}-12$, strain C600 (a non-producer of cytotoxin); lysogenic $E$. coli $\mathrm{K}-12$, strain C600 (933w) (SLT-II), kindly provided by A. D. O'Brien, Uniformed Services University of the Health Sciences, Bethesda, MD; and E. coli serotype O78:H11, strain H10407 (heat-labile and heat-stable enterotoxin). Other bacteria examined included 40 isolates of Shigella spp., ${ }^{7}$ 56 pathogenic and 10 nonpathogenic $E$. coli strains, ${ }^{29} 52$ Salmonella isolates, ${ }^{31} 10$ of Aeromonas spp., ${ }^{32}$ and 20 of Campylobacter spp. The E. coli strains included 14 isolates of $E$. coli serotype 0157:H7 from patients with haemorrhagic colitis, diarrhoea or HUS and three isolates of E. coli serotype $\mathrm{O} 26: \mathrm{H} 11$ from patients with diarrhoea.

\section{Preparation of polymyxin extracts}

Bacteria were grown on charcoal-yeast extract (CYE), blood and MacConkey agar plates, incubated overnight at $37^{\circ} \mathrm{C}$. Polymyxin B (Sigma) was diluted in phosphatebuffered saline (PBS; $0.2 \mathrm{M}$ sodium phosphate, $0.2 \mathrm{M}$ potassium phosphate) to the desired concentration. To determine the optimal polymyxin B extraction procedure, bacterial cells were incubated with polymyxin B concentrations of $0,0 \cdot 01,0 \cdot 1,0 \cdot 2,0 \cdot 5,1$ or $2 \mathrm{~g} / \mathrm{L}$ for periods of $2,5,10,20,30$ or $60 \mathrm{~min}$. For these experiments, E. coli O26:H11 strain H30, grown overnight on CYE, blood or MacConkey agar, was suspended in PBS to obtain a stock suspension of $c .10^{9} \mathrm{cfu} / \mathrm{ml}$ and $1-\mathrm{ml}$ volumes were placed in Eppendorf tubes and centrifuged in a microcentrifuge for $5 \mathrm{~min}$. Cell pellets were resuspended in PBS containing the range of concentrations of polymyxin $B$ and incubated in a water bath at $37^{\circ} \mathrm{C}$ for the test periods.
Samples were then centrifuged ( $5 \mathrm{~min})$ again and the supernates were sterilised by membrane filtration (pore size, $0.22 \mu \mathrm{m}$ ) and assayed for cytotoxicity. Protein concentration was determined by the Bio-Rad assay (BioRad Laboratories, Richmond, CA) with bovine serum albumin (BSA) as a standard. Assays were performed in duplicate and repeated at least three times. Control samples with polymyxin only were treated and assayed simultaneously. After these experiments, a standard extraction procedure was used with incubation for $30 \mathrm{~min}$ in polymyxin $B 0 \cdot 1 \mathrm{~g} / \mathrm{L}$.

\section{Detection of Shiga toxin and SLT-I in bacteria grown in pure culture}

S. dysenteriae 1 strain $60 \mathrm{R}$ (Shiga toxin) and E. coli O26:H11 strain H30 (SLT-I) were grown overnight on CYE, blood and MacConkey agar plates. A loopful (0.001-ml loop) of confluent bacterial growth was suspended in Eppendorf tubes containing $0.25 \mathrm{ml}$ of polymyxin B $0.1 \mathrm{~g} / \mathrm{L}$ in PBS. After incubation for $30 \mathrm{~min}$ at $37^{\circ} \mathrm{C}$, samples were processed as above. To compare the yields obtained by sonic extraction and by polymyxin extraction, 1-ml samples of a stock suspension of E. coli $\mathrm{H} 30\left(10^{9} \mathrm{cfu} / \mathrm{ml}\right.$ in PBS) were extracted by polymyxin (as above) or by sonication, ${ }^{29}$ and the amounts of cytotoxin obtained were measured. Negative control reference strains were grown, extracted and assayed simultaneously.

\section{Detection of SLT-I from a mixed culture}

E. coli $\mathrm{O} 26$ : $\mathrm{H} 11$ strain $\mathrm{H} 30$ and E. coli $\mathrm{K}-12$ strain C600 were each grown overnight on CYE plates, washed in PBS and resuspended in PBS to a final concentration of $10^{9} \mathrm{cfu} / \mathrm{ml}$. Appropriate volumes of the two suspensions were mixed to obtain mixtures in which the proportion of $E$. coli $\mathrm{H} 30$ was $1,5,10,30$ or $50 \%$. Controls were pure suspensions of E. coli $\mathrm{H} 30$ and E. coli $\mathrm{C} 600$. Each mixture $(100 \mu \mathrm{l})$ was plated on CYE agar and incubated overnight. A loopful of confluent bacterial growth from each mixture was suspended in an Eppendorf tube containing $0.25 \mathrm{ml}$ of polymyxin $\mathrm{B} 0.1 \mathrm{~g} / \mathrm{L}$ in PBS, incubated for $30 \mathrm{~min}$ at $37^{\circ} \mathrm{C}$ and processed as above.

\section{Preparation of purified Shiga toxin}

Purified Shiga toxin was used in titration curves to determine the amount of toxin obtained by the extraction procedures. Toxin was purified from a sonic extract of $S$. dysenteriae serotype 1 strain $60 \mathrm{R}$ by chromatography with an Affi-Gel Blue column, chromatofocusing, and a hydroxylapatite column, as described previously. ${ }^{30}$ The purified toxin had a specific activity of $10^{7 \cdot 3} 50 \%$ cytotoxic doses (CD50)/mg of protein.

\section{Preparation of anti-Shiga toxin serum}

Rabbit anti-Shiga toxin serum, which also neutralised SLT-I, was obtained by repeated injections of formalde- 
hyde-treated purified Shiga toxin ( $100 \mu \mathrm{g} /$ dose) as previously described. ${ }^{7}$

\section{$\mathrm{Gb}_{3} \mathrm{ELISA}$}

The assay was performed as described previously. ${ }^{25}$ $\mathrm{Gb}_{3}$ (Supelco, Bellefonte, PA) was diluted in chloroform:methanol $(2: 1)$ to a concentration of $5 \mu \mathrm{g} / \mathrm{ml}$ and inoculated $(100 \mu \mathrm{l} /$ well $)$ on to polyvinyl chloride microtitration plates (Dynatech Laboratories, Inc., Alexandria, VA). Plates were left uncovered overnight so that the diluent evaporated and $\mathrm{Gb}_{3}$ attached to the plates. After blocking with BSA $(50 \mathrm{~g} / \mathrm{L}, 200 \mu \mathrm{l} /$ well, $1 \mathrm{~h})$, test samples were added $(100 \mu \mathrm{l} /$ well, $1 \mathrm{~h})$. Bound toxin was detected by monoclonal antibodies and peroxidase-conjugated rabbit anti-mouse antibodies as described previously. ${ }^{25}$

Reproducibility of the extraction procedure and the assay was determined by duplicate testing. Sensitivity was determined by titration with purified Shiga toxin and comparing the readings with those obtained by polymyxin extraction of reference strains that produce Shiga toxin or SLT-I. Specificity was determined by examining crossreactivity with polymyxin extracts of well characterised bacterial strains that produce enterotoxins (E. coli H10407), SLT-II (E. coli C600 [933w]) or were cytotoxin non-producers (E.coli C600), and of various other cytotoxin-producing bacterial isolates (table).

\section{Cytotoxicity and neutralisation assays}

Quantitative cytotoxic activity was determined by overnight incubation of cell-free toxin preparations with $\left[\mathrm{H}^{3}\right]$ thymidine-labelled $\mathrm{HeLa}$ cells as described previously. ${ }^{29}$ Radioactivity of attached viable cells was counted and results were expressed as a percentage of HeLa cell survival in comparison with control wells without toxin. The CD50 was calculated from the linear regression of the percentage of HeLa cell survival versus the $\log _{10}$ toxin dilution. ${ }^{7}$ Neutralisation was studied by pre-incubation of the toxin for $4 \mathrm{~h}$ at $37^{\circ} \mathrm{C}$ with rabbit anti-Shiga toxin serum or rabbit non-immune serum (control) followed by determination of cytotoxicity with radiolabelled HeLa cells as described above.

\section{DNA hybridisation studies}

The DNA probe for SLT-I described by J. W. Newland and R. J. Neill (Walter Reed Army Institute of Research, Washington, DC) was used. The probe is a $1 \cdot 142-\mathrm{kb}$ BamHI fragment of the recombinant plasmid pJN37-19, cloned from $E$. coli bacteriophage 933J. ${ }^{34}$ As Shiga toxin and SLT-I differ in only three nucleotides, the SLT-I probe also hybridises with Shiga toxin-producing organisms. The probe was extracted from low temperature gelling agarose and labelled by nick translation with ${ }^{32} \mathrm{P}-$ labelled 5'-dCTP (Dupont, NEM Research Products, Boston, MA). Bacterial colonies were transferred to Whatman 541 filter papers, lysed as described previously, ${ }^{35}$ and hybridised under stringent conditions- formamide $50 \%, 42^{\circ} \mathrm{C}, 2 \times \mathrm{SSC}$ (SSC is $0.5 \mathrm{M} \mathrm{NaCl}+$ $0.015 \mathrm{~m}$ sodium citrate), $18 \mathrm{~h}$. The following positive and negative control strains were placed on each filter: $S$.dysenteriae serotype 1 strain 60R, E. coli $\mathrm{O} 26: \mathrm{H} 11$ strain $\mathrm{H} 30, E$. coli $\mathrm{C} 600$ (933w) and E. coli C600.

\section{Results}

\section{Polymyxin B extraction}

In experiments to optimise the conditions of our novel method of polymyxin extraction, which included direct inoculation from primary plates to polymyxin suspension and detection by $\mathrm{Gb}_{3}$ ELISA, the amounts of Shiga toxin and SLT-I released increased with increasing concentrations of polymyxin $(0-0.1 \mathrm{~g} / \mathrm{L})$; a plateau of release was reached at $0 \cdot 1 \mathrm{~g} / \mathrm{L}$. With this concentration of polymyxin, optimal release of cytotoxin was achieved by incubation for $10-60 \mathrm{~min}$. In subsequent experiments, the standard extraction conditions used were polymyxin $0 \cdot 1 \mathrm{~g} / \mathrm{L}$ and incubation for $30 \mathrm{~min}$ at $37^{\circ} \mathrm{C}$.

\section{Detection of cytotoxin from pure cultures}

Shiga toxin and SLT-I were detected by standard polymyxin extraction and $\mathrm{Gb}_{3}$ ELISA from pure cultures on agar media. Positive results were obtained with $S$. dysenteriae 1 strain 60R (Shiga toxin), E. coli O26:H11 strain H30 (SLT-I) and E. coli O157:H7 (SLT-I). There was no crossreactivity with $E$. coli $\mathrm{O} 78: \mathrm{H} 11 \mathrm{H} 10407$ (enterotoxin), E. coli C600 (933w) (SLT-II) or E. coli C600 control strains examined simultaneously. The range of readings $\left(\mathrm{OD}_{490}\right)$ of these negative-control reference strains was $0.01-0.04$ (mean $0.03 \mathrm{SD}$ 0.01 ). Readings of $\geqslant 0.1$ were considered to be positive results. According to the titration curve, this reading represented $0.2-0.5 \mathrm{ng}$ of purified Shiga toxin per well. Positive results were obtained with 11 clinical isolates of $E$. coli $\mathrm{O} 157: \mathrm{H} 7$ or $E$. coli O26: H11 from patients with haemorrhagic colitis, diarrhoea or HUS. None of the polymyxin extracts of various other cytotoxin-producing bacteria, including other strains of Shigella, pathogenic and non-pathogenic E. coli, Salmonella, Aeromonas and Campylobacter showed cross-reactivity in the assay (table).

\section{Comparison of polymyxin and sonic extraction}

In parallel tests with the same number of bacteria from a stock suspension, the yields of toxin from polymyxin-treated and sonicated cells were com- 
Table. Detection of Shiga toxin and SLT-I in polymyxin B extracts of cytotoxin-producing bacteria by $\mathrm{Gb}_{3}$ ELISA and HeLa cell cytotoxicity assay

\begin{tabular}{|c|c|c|}
\hline \multirow[b]{2}{*}{ Bacterial strains } & \multicolumn{2}{|c|}{ Results obtained by } \\
\hline & $\begin{array}{c}\mathrm{Gb}_{3} \\
\text { ELISA* }\end{array}$ & $\begin{array}{l}\text { Cytotoxicity } \\
\text { assay } \dagger\end{array}$ \\
\hline \multicolumn{3}{|l|}{ Reference strains (toxin) } \\
\hline S. dysenteriae serotype 1 strain $60 \mathrm{R}$ (Shiga toxin) $\ddagger$ & + & + \\
\hline E. coli serotype $\mathrm{O} 26: \mathrm{H} 11$ strain $\mathrm{H} 30$ (SLT-I) $\ddagger$ & + & + \\
\hline E. coli serotype 0157:H7 (SLT-I)‡ & + & + \\
\hline E. coli serotype O78:H11 strain H10407 (enterotoxins) $\S$ & - & - \\
\hline E. coli C600 (933w) (SLT-II)§ & - & - \\
\hline E. coli $\mathrm{C} 600 \S$ & - & - \\
\hline \multicolumn{3}{|l|}{ Clinical isolates (number of strains) } \\
\hline S. dysenteriae $1(10)$ & + & + \\
\hline S. sonnei $(13) \S$ & - & - \\
\hline S. flexneri $(13) \S$ & - & - \\
\hline S. boydii (4)§ & - & - \\
\hline Nonpathogenic $E$. coli $(10)$ & - & - \\
\hline \multicolumn{3}{|l|}{ Pathogenic E. coli } \\
\hline EAEC (10) & - & - \\
\hline $\operatorname{EIEC~(30)}$ & - & - \\
\hline EPEC (6) & - & - \\
\hline ETEC (10) & - & - \\
\hline E. coli $\mathrm{O} 26: \mathrm{H} 11$ (SLT-I) (3) & + & + \\
\hline E. coli O157:H7 (SLT-I) (8) & + & + \\
\hline E. coli O157:H7 (SLT-II) (6) & - & - \\
\hline Sal. enteritidis (25)§ & - & - \\
\hline Sal. typhi (12)§ & - & - \\
\hline Sal. choleraesuis (15)§ & - & - \\
\hline A. hydrophila (10) & - & - \\
\hline C. jejuni (20) & - & - \\
\hline
\end{tabular}

EAEC, entero-adherent $E$. coli (as defined by Mathewson $e t$ al.; ${ }^{33}$ ) EIEC, entero-invasive $E$. coli; EPEC, enteropathogenic E. coli; ETEC, enterotoxigenic E. coli.

,$+ \mathrm{OD}_{490} \geqslant 0 \cdot 1$.

$\dagger+$, Cytotoxic activity present, neutralised with anti-Shiga toxin serum.

‡ Structural genes for Shiga toxin (or SLT-I) demonstrated by DNA hybridisation.

$\S$ Structural genes for Shiga toxin (or SLT-I) not present.

pared. Polymyxin treatment gave lower OD readings $-65-90 \%$ of these obtained with sonicated bacteria (fig. 1a). Similar results were obtained with bacteria grown on CYE, blood and MacConkey agars. However, when readings were translated into amounts of toxin $(\mu \mathrm{g}) / \mathrm{mg}$ of bacterial protein (specific activity), the amounts of toxin extracted were five-fold higher with polymyxin treatment than with sonication (fig. 1b).

\section{Detection of SLT-I from mixed culture}

$\mathrm{Gb}_{3}$ ELISA was used to detect SLT-I in polymyxin extracts of a mixed culture of SLT-I-positive and-negative strains. Positive results were obtained when the proportion of the SLT-I-positive strain (E. coli $\mathrm{H} 30$ ) was as low as $1 \%$ (fig. 2). A plateau was reached when the SLT-I-positive strain was c. $10 \%$ of the mixture. Pure growth of the toxinnegative strain $(E$. coli $\mathrm{C} 600)$ gave negative results under the same experimental conditions.

\section{Correlation with HeLa cell cytotoxicity assay and with DNA hybridisation}

The cell-free polymyxin extracts were examined for cytotoxicity. The cut-off point of the assay $\left(\mathrm{OD}_{490}\right.$ 0.1) corresponded to about 10-30 CD50. Extracts of control strains that gave positive results in the $\mathrm{Gb}_{3}$ ELISA, whether from pure or mixed cultures, were cytotoxic in the radiolabelled $\mathrm{HeLa}$ cell assay, and the cytotoxicity was neutralised by rabbit antiserum to Shiga toxin. Extracts of negative control strains were not cytotoxic. In tests with polymyxin extracts of other bacteria, strains that gave positive results for Shiga toxin or SLT-I 

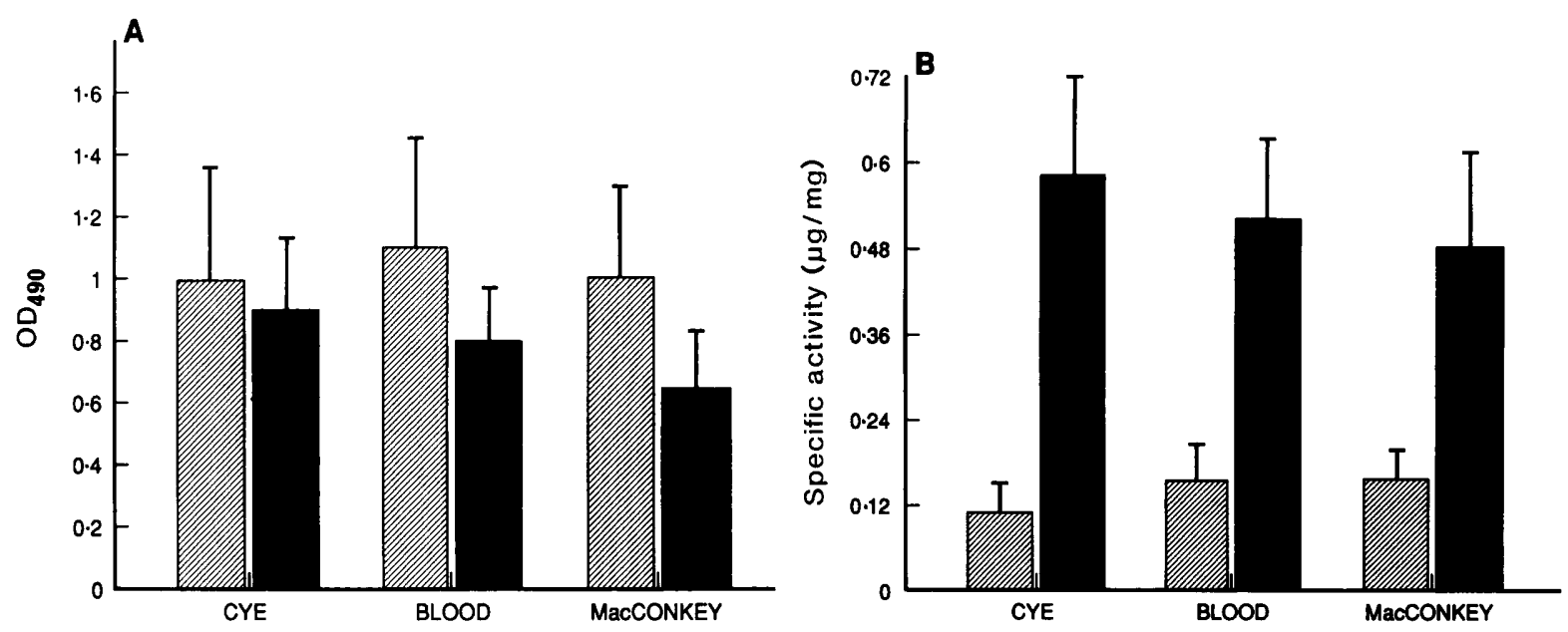

Fig. 1. Amounts of SLT-I detected by $\mathrm{Gb}_{3}$ ELISA in polymyxin $\square$ and sonic $\mathbb{Z}$ extracts of E. coli $\mathrm{O} 26: \mathrm{H} 11$ strain $\mathrm{H} 30$ grown in three media. (A) $\mathrm{OD}_{490}$ values in the $\mathrm{Gb}_{3}$ ELISA. (B) Specific activity (amount of toxin/total bacterial protein, $\mu \mathrm{g} / \mathrm{mg}$ ) in each extract, determined from titration curve with purified toxin and Bio-Rad assay for total protein. Results are means (SD) of three determinations.

(neutralised by rabbit antiserum to Shiga toxin) in the cytotoxicity assay or hybridised with the DNA probe for SLT-I, also gave positive results in the $\mathrm{Gb}_{3}$ ELISA. Polymyxin extracts that gave negative results in the cytotoxicity assay (no neutralisation with the anti-Shiga toxin serum) and in DNA hybridisation also gave negative results in the $\mathrm{Gb}_{3}$ ELISA (table).

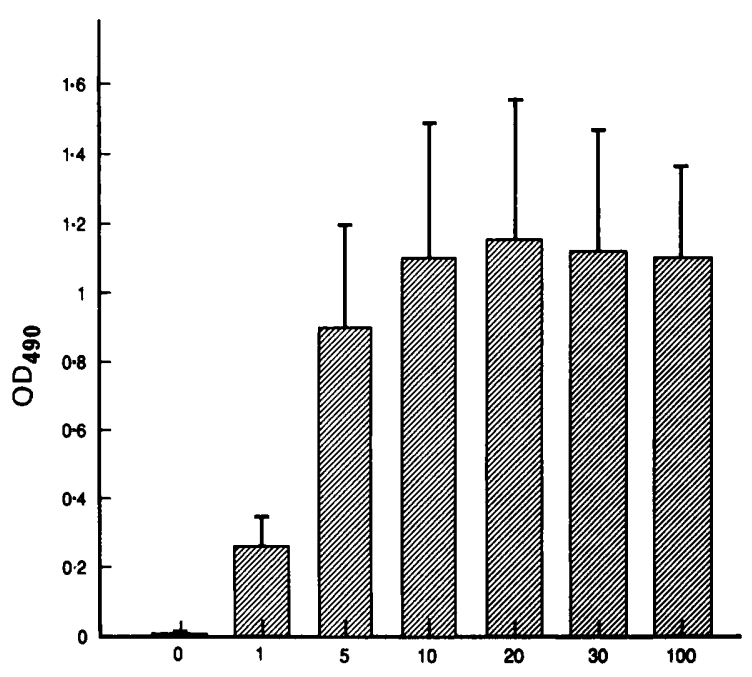

Strain $\mathrm{H} 30$ percentage in mixture

Fig. 2. Detection by $\mathrm{Gb}_{3}$ ELISA of SLT-I from polymyxin extracts of cultures of $E$. coli $\mathrm{O} 26: \mathrm{H} 11$ strain $\mathrm{H} 30(0-100 \%)$ with toxin-negative $E$. coli C600. Results are means (SD) of three determinations.

\section{Discussion}

Several approaches have been used for the diagnosis of cytotoxin-related diarrhoeal disease and HUS. Initial attempts have concentrated on isolating E. coli serotype $\mathrm{O} 157: \mathrm{H} 7$ by culture of MacConkey-sorbitol agar and on developing rapid diagnostic tests. ${ }^{36,37}$ However, although E. coli O157:H7 is the most frequent serotype associated with haemorrhagic colitis and HUS, many other serotypes are involved. Therefore, the diagnostic approach should be directed toward detection of either cytotoxin-producing organisms or free cytotoxin activity. Detection of the genes encoding the relevant toxins in bacterial cells by radiolabelled DNA probes, either restriction fragments ${ }^{8,34}$ or synthetic oligonucleotide probes, ${ }^{21}$ has been used effectively, but concern over handling radioactive materials may make them unsuitable for routine use in a clinical diagnostic laboratory.

Detection of cytotoxins from bacterial isolates or stool extracts is usually based on morphological changes (cytopathic effect) in HeLa or Vero cells. These assays take several days and require facilities for and experience with tissue cultures. Neutralisation studies to identify the toxin are sometimes difficult to interpret due to variable cell growth, ${ }^{24}$ and because the sensitivity of various cell lines to cytotoxins varies significantly. ${ }^{18}$ Simple and rapid assays are needed for routine detection of cytotoxins.

Rapid ELISA methods to detect Shiga toxin and SLTs by binding to monoclonal antibody or to the toxin receptor have been described. ${ }^{22-24,38}$ They 
seem to be sensitive and specific and can facilitate cytotoxin detection. However, toxin detection is usually based on examination of individual colonies. This may present a significant problem because the proportion of cytotoxin-producing colonies in stool samples from patients with diarrhoea, and especially with HUS, may be $\leqslant$ $5 \% \cdot{ }^{4,28}$ Therefore many colonies must be screened, which is cumbersome and impractical for clinical laboratories. Downes et al. used ELISA to detect cytotoxins in stool extracts, but they were unable to detect SLT-I because it was present in small quantities. ${ }^{24}$

Polymyxin extraction has been used to release Shiga toxin and SLTs from Shigella and E. coli strains $;{ }^{26,27}$ the toxin released was similar to that obtained by sonic extraction. ${ }^{26}$ Polymyxin extraction of colony sweeps has been used successfully to detect cytotoxins from a mixed culture. ${ }^{27}$ However, although the extraction procedure was rapid and simple, colony sweeps were inoculated into broth and incubated for $5 \mathrm{~h}$, and the cytotoxicity assay was based on morphological changes in Vero cells after $72 \mathrm{~h}$, so that rapid diagnosis was not achieved.

In this study, we used polymyxin extraction, but attempted to detect cytotoxin directly from bacterial growth on readily available culture media by a rapid and simple receptor binding assay $\left(\mathrm{Gb}_{3}\right.$ ELISA). The optimal conditions for polymyxin extraction directly from culture plates were similar to those described previously for extraction from bacteria grown in broth ${ }^{26,27}$ and the standard extraction conditions used were polymyxin $0.1 \mathrm{~g} / \mathrm{L}$, for $30 \mathrm{~min}$ at $37^{\circ} \mathrm{C}$.

We have shown that polymyxin extraction of bacterial growth from agar plates and $\mathrm{Gb}_{3}$ ELISA may be useful in the diagnosis of infections with bacteria that produce Shiga toxin and SLT-I. The sensitivity was surprisingly high; cytotoxin was detected in polymyxin extracts of a mixed culture when the proportion of the cytotoxin-producing strain was as low as $1 \%$. This high sensitivity is probably because of the small volume $(0.25 \mathrm{ml})$ in which bacteria were suspended and optimal condi-

\section{REFERENCES}

1. Karmali MA. Infection by verocytotoxin-producing Escherichia coli. Clin Microbiol Rev 1989; 2: 15-38.

2. Riley LW, Remis RS, Helgerson SD et al. Hemorrhagic colitis associated with rare Escherichia coli serotype. $N$ Engl J Med 1983; 308: 681-685.

3. Scotland SM, Willshaw GA, Smith HR, Rowe B. Properties of strains of Escherichia coli belonging to serogroup 0157 with special reference to production of Vero tions for polymyxin extraction. The assay was very specific-no cross-reactivity was found with enterotoxins, SLT-II or other cytotoxin-producing organisms, including other Shigella or E. coli strains and Salmonella, Campylobacter or Aeromonas strains. These results were in agreement with a radiolabelled cytotoxicity assay with neutralisation by specific antiserum, and with DNA hybridisation tests for the structural genes for toxin production. $A s \mathrm{~Gb}_{3}$ is also the binding receptor of SLT-II, ${ }^{39}$ the latter toxin may be detected also by the same method with appropriate antibodies to SLT-II. It would be very useful if polymyxin extraction and plates precoated with $\mathrm{Gb}_{3}$ could be used to detect both toxins, with specific identification of bound toxin by different antibodies.

The sensitivity of our assay was $0 \cdot 2 \mathrm{ng}$ of purified toxin per well, similar to that described by Downes et al. ${ }^{24}$ but lower than that described in two other assays $;^{24,38}$ it correlates with $c .10-30$ CD50 in the $\mathrm{HeLa}$ cell cytotoxicity assay. Although $\mathrm{Gb}_{3}$ ELISA is slightly less sensitive than the cytotoxicity assay, it is specific, rapid, and easier to perform and interpret. The slightly lower sensitivity did not prevent detection of toxin from mixed culture, even when the proportion of the toxin-positive strain was only $1 \%$. Low level cytotoxin-producing strains may not be detected by this assay, but their relevance to human disease is questionable. ${ }^{1}$

Rapid and simple extraction and detection methods are necessary for routine use in clinical laboratories. They should be useful in large scale epidemiological studies of cytotoxin-related infections. Early diagnosis of these infections may be helpful in controlling person-to-person transmission and evaluating the efficacy of various therapeutic measures on the course of cytotoxin-related diarrhoeal disease and on the development of HUS.

We thank Dr Barbara E. Murray for help with the DNA hybridisation studies, Delores Reich for technical assistance, and Anne Wright for preparing the manuscript. This study was supported by a Public Health Service grant HD-13021 from the National Institutes of Health and by a grant from the Thrasher Research Fund. cytotoxin VT1 and cytotoxin VT2. Epidemiol Infect 1987; 99: 613-624.

4. Karmali MA, Petric M, Lim C, Flemming PC, Arbus GS, Lior $\mathrm{H}$. The association between idiopathic hemolytic uremic syndrome and infection by Verotoxin-producing Escherichia coli. J Infect Dis 1985; 151 : 775-782.

5. Neill MA, Tarr PI, Clausen CR, Christie DL, Hickman RO. Escherichia coli $0157: \mathrm{H} 7$ as the predominant pathogen associated with the hemolytic uremic syndrome: a prospective study in the Pacific Northwest. 
Pediatrics $1987 ; 80: 37-40$.

6. Cleary TG. Cytotoxin-producing Escherichia coli and hemolytic uremic syndrome. Pediatr Clin North Am 1988; 35 : $485-501$.

7. Bartlett AV, Prado D, Cleary TG, Pickering LK. Production of Shiga toxin and other cytotoxins by serogroups of Shigella.J Infect Dis 1986; 154: 996-1002.

8. Newland JW, Neill RJ. DNA probes for Shiga-like toxins I and II and for toxin-converting bacteriophages. $J$ Clin Microbiol 1988; 26: 1292-1297.

9. Konowalchuk J, Speirs JI, Stavric S. Vero response to a cytotoxin of Escherichia coli. Infect Immun 1977; 18: 775-779.

10. Strockbine NA, Marques LRM, Newland JW, Smith HW, Holmes RK, O'Brien AD. Two toxin-converting phages from Escherichia coli $\mathrm{O} 157: \mathrm{H} 7$ strain 933 encode antigenically distinct toxins with similar biologic activities. Infect Immun 1986; 53: 135-140.

11. Strockbine NA, Marques LRM, Holmes RK, O'Brien AD. Characterization of monoclonal antibodies against Shiga-like toxin from Escherichia coli. Infect Immun 1985; 50: 695-700.

12. Perera LP, Marques LRM, O'Brien AD. Isolation and characterization of monoclonal antibodies to Shigalike toxin II of enterohemorrhagic Escherichia coli and use of the monoclonal antibodies in a colony enzymelinked immunosorbent assay. J Clin Microbiol 1988; 26: 2127-2131.

13. Jackson MP, Newland JW, Holmes RK, O'Brien AD. Nucleotide-sequence analysis of the structural genes for Shiga-like toxin I encoded by bacteriophage 933J from Escherichia coli. Microb Pathog 1987; 2: 147-153.

14. Fuchs G, Mobassaleh M, Donohue-Rolfe A, Montgomery RK, Grand RJ, Keusch GT. Pathogenesis of shigella diarrhea: rabbit intestinal cell microvillus membrane binding site for shigella toxin. Infect Immun 1986; 53: 372-377.

15. Jacewicz M, Clausen H, Nudelman E, Donohue-Rolfe A, Kensch GT. Pathogenesis of shigella diarrhea. XI. Isolation of a shigella toxin-binding glycolipid from rabbit jejunum and HeLa cells and its identification as globotriaosylceramide. J Exp Med 1986; 163: 13911404.

16. Lindberg AA, Brown JE, Stromberg $\mathrm{N}$ et al. Identification of the carbohydrate receptor for Shiga toxin produced by Shigella dysenteriae type $1 . J$ Biol Chem 1987; 262: 1779-1785.

17. Lingwood CA, Law H, Richardson SE et al. Glycolipid binding of purified and recombinant Escherichia coli produced verotoxin in vitro. $J$ Biol Chem 1987; 262: 8834-8839.

18. O'Brien AD, Holmes RK. Shiga and Shiga-like toxins. Microbiol Rev 1987; 51: 206-220.

19. Weinstein DL, Jackson MP, Samuel JE, Holmes RK, O'Brien AD. Cloning and sequencing of a Shiga-like toxin type II variant from an Escherichia coli strain responsible for edema disease of swine. $J$ Bacteriol $1988 ; 170$ : 4223-4230.

20. Oku Y, Yutsudo T, Hirayama T, O'Brien AD, Takeda Y. Purification and some properties of a Vero toxin from a human strain of Escherichia coli that is immunologically related to Shiga-like toxin II (VT2). Microb Pathog $1989 ; 6: 113-122$.

21. Karch H, Meyer T. Evaluation of oligonucleotide probes for identification of Shiga-like-toxin-producing Escherichia coli. J Clin Microbiol 1989; 27 : 1180-1186.

22. Donohue-Rolfe A, Kelley MA, Bennish M, Keusch GT.
Enzyme-linked immunosorbent assay for shigella toxin. $J$ Clin Microbiol 1986; $24: 65-68$.

23. Kongmuang U, Honda T, Miwatani T. Enzyme-linked immunosorbent assay to detect Shiga toxin of Shigella dysenteriae and related toxins. J Clin Microbiol 1987; 25: $115-118$.

24. Downes FP, Green JH, Greene K, Stockbrine W, Wells JG, Wachomūlh IK. Development and evaluation of enzyme-linked immunosorbeo assays for detection of Shiga-like toxin I and Shiga-like toxin II. J Clin Microbiol 1989; 27 : 1292-1297

25. Ashkenazi S, Cleary TG. Rapid method to detect Shiga toxin and Shiga-like toxin I based on binding to globotriosyl ceramide $\left(\mathrm{Gb}_{3}\right)$, their natural receptor. $J$ Clin Microbiol 1989; 27: 1145-1150.

26. Griffin DE, Gemski P. Release of Shiga toxin from Shigella dysenteriae 1 by polymyxin B. Infect Immun 1983; 40: 425-428.

27. Karmali MA, Petric M, Lim C, Cheung R, Arbus GS. Sensitive methods for detecting low numbers of verotoxin-producing Escherichia coli in mixed cultures by use of colony sweeps and polymyxin extraction of verotoxin. J Clin Microbiol 1985; 22 : 614-619.

28. Scotland SM, Rowe B, Smith HR, Willshaw GA, Gross RJ. Verocytotoxin-producing strains of Escherichia coli from children with haemolytic uraemic syndrome and their detection by specific DNA probes. J Med Microbiol $1988 ; 25: 237-243$.

29. Cleary TG, Mathewson JJ, Faris E, Pickering LK. Shigalike cytotoxin production by enteropathogenic Escherichia coli serogroups. Infect Immun 1985; 47: 335-337.

30. Prado D, Cleary TC, Pickering LK et al. The relation between production of cytotoxin and clinical features of shigellosis. J Infect Dis 1986; 154: 149-155.

31. Ashkenazi S, Cleary TG, Murray BE, Wanger A, Pickering LK. Quantitative analysis and partial characterization of cytotoxin production by Salmonella strains. Infect Immun 1988; 56: 3089-3094.

32. Kindschuh M, Pickering LK, Cleary TG, Ruis-Palacios G. Clinical and biochemical significance of toxin production by Aeromonas hydrophila. J Clin Microbiol 1987; 25: $916-921$.

33. Mathewson JJ, Cravioto A. HEp-2 adherence as an assay for virulence among diarrheagenic Escherichia coli. $J$ Infect Dis 1989; 159: 1057-1060.

34. Newland JW, Strockbine NA, Miller SF, O'Brien AD, Holmes RK. Cloning of Shiga-like toxin structural genes from a toxin converting phage of Escherichia coli. Science 1985; 230: 179-181.

35. Maas R. An improved colony hybridization method with significantly increased sensitivity for detection of single genes. Plasmid 1983; 10: 296-298.

36. Perry MB, Bundle DR, Gidney MAJ, Lior H. Identification of Escherichia coli serotype O157 strains by using a monoclonal antibody. J Clin Microbiol 1988; 26: 23912394.

37. March SB, Ratnam S. Latex agglutination test for detection of Escherichia coli serotype O157. J Clin Microbiol 1989; 27: 1675-1677.

38. Basta M, Karmali M, Lingwood C. Sensitive receptorspecific enzyme-linked immunosorbent assay for Escherichia coli verotoxin. J Clin Microbiol 1989; 27 : 16171622.

39. Waddell T, Head S, Petric M, Cohen A, Lingwood C. Globotriosyl ceramide is specifically recognized by the Escherichia coli Vero cytotoxin 2. Biochem Biophys Res Commun 1988; 152: 674-679. 
